\title{
SOSIALISME ISLAM: PERSPEKTIF PEMIKIRAN POLITIK H.O.S. TJOKROAMINOTO
}

\author{
Firman Manan \\ Departemen Ilmu Politik FISIP Universitas Padjadjaran \\ E-mail: firman.manan@unpad.ac.id
}

\begin{abstract}
In several literatures of Indonesian political thought, the ideas of socialism has been claimed as the doctrine came from and influenced by western political thought. On the other side, Islam political thought has been seemed as the doctrine came from Indonesia traditional heritages. These view was rejected by H.O.S. Tjokroaminoto who argues that socialism has been established and flourished in the Islamic tradition before it was developed in the West. This article tries to describe H.O.S. Tjokroaminoto's political thought about Islamic socialism which was constructed in the Islamic tradition rooted from Al-Quran and As-Sunnah.
\end{abstract}

Key words: socialism, political thought, Islam

\begin{abstract}
ABSTRAK
Dalam beberapa literatur tentang pemikiran politik di Indonesia, ajaran sosialisme diklaim sebagai ajaran yang berasal dan dipengaruhi oleh arus pemikiran barat. Di sisi lain, pemikiran politik Islam dilihat sebagai ajaran yang berasal dari warisan tradisional asli Indonesia. Pandangan tersebut ditolak oleh H.O.S. Tjokroaminoto yang mengemukakan argumentasi bahwa sosialisme telah lahir, tumbuh dan berkembang dalam tradisi Islam jauh sebelum kelahiran sosialisme di Barat. Artikel ini berupaya untuk mendeskripsikan pemikiran politik H.O.S. Tjokroaminoto tentang sosialisme Islam yang dikonstruksikan dalam tradisi Islam dan berakar dari Al-Quran serta As-Sunnah.
\end{abstract}

Kata kunci: sosialisme, pemikiran politik, Islam

\section{PENDAHULUAN}

RadenMasHajiOemarSaidTjokroaminoto atau dikenal dengan H.O.S Tjokroaminotomerupakan salah satu tokoh pergerakan nasional yang memberikan pengaruh besar dalam dinamika politik Indonesia, termasuk di dalamnya membentuk pemikiran politik maupun mempengaruhi tindakan politik banyak tokoh pergerakan nasional. H.O.S. Tjokroaminoto terlahir dari keluarga ningrat dan sekaligus keturunan ulama, karena buyutnya adalah Kyai Bagoes Kesan Besari yang merupakan kyai ternama di daerah Ponorogo yang memperistri putri dari Susuhunan II (Gonggong, 1985:7). Kakek dan ayahnya berkarier sebagai pegawai pemerintah (pamong praja), karier yang pada awalnya juga dipilih oleh Tjokroaminoto setelah menyelesaikan studi di Opleidings School Voor Indlandsche Ambtenaren (OSVIA) di Magelang pada tahun 1902. Latar belakang keluarga dan pendidikan yang dimiliki oleh Tjokroaminoto dengan demikian menunjukkan status sosial yang tinggi, selain juga latar belakang agama Islam yang relatif kuat melekat pada dirinya.

Tjokroaminoto merupakan guru politik sekaligus teman diskusi terhadap beberapa tokoh pergerakan nasional seperti Soekarno, Kartosoewiryo, Abikoesno, Alimin dan Muso. Bahkan, Soekarnoyang dikemudian harimenjadi Presiden Republik Indonesia pertama, pernah menjadi menantu dari Tjokroaminoto, walaupun pernikahan tersebut diakui oleh Soekarno sebagai bentuk penghormatan dan rasa kasihan terhadap Tjokroaminoto sehingga pernikahannya dengan Oetari - putri Tjokroaminoto - hanyalah berupa kawingantung (Adams, 1966:38) Menariknya, beberapa murid Tjokroaminoto memiliki pandangan politik yang berbeda dalam perkembangan pemikiran politik serta ideologi politik yang dianutnya. Soekarno sangat dipengaruhi dan kemudian mengembangkan ajaran nasio- 
nalisme, Kartosoewiryo menganut ajaran fundamentalisme Islam, sementara Alimin dan Muso mengembangkan ajaran komunisme (Rambe, $2008: 75$ ).

H.O.S Tjokroaminoto juga merupakan tokoh yang tidak dapat dilepaskan dari perkembangan organisasi Syarikat Islam (SI) yang kemudian berubah menjadi Partai Sarikat Islam (PSI) dan Partai Syarikat Islam Indonesia (PSII). Tjokroaminoto merupakan Ketua Syarikat Islam dan menjadi pemimpin PSI dan PSII hingga akhir hayatnya. Tjokroaminoto merupakan tokoh yang paling berpengaruh dalam sejarah Syarikat Islam (Subekti, 2014: 23).

Besarnya pengaruh Tjokroaminoto dalam SI dapat terlihat dari bagaimana kader-kader partai tersebut memperlakukannya sebagai tokoh kharismatis yang amat dihormati dan diidolakan kaum partai. Penghormatan terlihat dengan gelar yang digunakan dalam partainya yaitu 'Yang Utama H.O.S. Tjokroaminoto', dan juga diciptakan lagu khusus 'Hymne H.O.S. Tjokroaminoto' yang dinyanyikan pada acara-acara resmi partai (Subekti, 2014: 133). Bahkan di sebagian kalangan masyarakat Tjokroaminoto dianggap sebagai ratu adil yang membawa kebenaran dan memimpin jalan ke surga (Niel, 2009: 158).

Sebagai seorang tokoh pergerakan yang juga merupakan tokoh Islam politik, salah satu pemikiran H.O.S. Tjokroaminoto yang memberikan pengaruh besar terhadap perkembangan SI, PSI dan PSII secara khusus dan terhadap pemikiran politik Islam Indonesia secara umum adalah pemikiran politiknya tentang sosialisme Islam. Tjokroaminoto dengan demikian merupakan tokoh pergerakan sekaligus tokoh muslim yang meletakkan dasar pemikiran politik yang menghubungkan antara ajaran Islam dan pemikiran sosialisme di Indonesia.

Tulisan ini akan mencoba mendeskripsikan pemikiran politik H.O.S. Tjokroaminoto tentang sosialisme Islam. Pendeskripsian pemikiran politik Tjokroaminoto tersebut dilakukan dengan maksud memberikan penjelasan apakah perkembangan pemikiran sosialisme Islam di Indonesia terutama yang dipengaruhi oleh pemikiran Tjokroaminoto - merupakan penggabungan tradisi pemikiran Islam dengan tradisi pemikiran sosialismeyang berakar dari Barat atau merupakan pemikiran politik yang murni berakar dari tradisi pemikiran Islam.

\section{PEMBAHASAN}

Dalambeberapaliteraturtentang pemikiran politik di Indonesia, ajaran sosialisme dipandang sebagai ajaran yang bersumber dari pengaruh asing, utamanya pengaruh barat (western influence). Argumentasi sebagaimana tersebut di atas misalnya dikemukakan oleh Herbert Feith dan Lance Castles ketika membahas tentang arus pemikiran politik Indonesia, yang menyatakan bahwa pengaruh ideologis yang berasal dari barat direpresentasikan oleh marxisme, baik dalam bentuk leninist maupun sosial-demokratik. Pengaruh tersebut kemudian menjelma antara lain ke dalam Partai Komunis Indonesia yang dipengaruhi paham komunisme serta Partai Sosialis Indonesia yang dipengaruhi paham sosialisme-demokrat (Feith and Castles, 2007: 15).

Di sisi lain, Feith dan Castles mengemukakan pengaruh Islam yang merupakan bagian dari arus pemikiran politik yang berasal dari tradisi, disamping pengaruh yang berasal dari Hindu-Jawa. Pemikiran Islam terbagi menjadi pemikiran yang dianut oleh kelompok reformis yang diwakili oleh Partai Masyumi dan kelompok konservatif yang direpresentasikan oleh Nahdlatul Ulama. Selain pengaruh Islam, Partai Masyumi juga dipengaruhi oleh pengaruh non-Islam yaitu pemikiran sosial-demokratik (Feith and Castles, 2007: 15-16).

Apabila mengacu pada pandangan tersebut di atas, pemikiran politik Islam dan pemikiran politik sosialisme diasumsikan berasal dari dua arus pemikiran politik yang berbeda. Pemikiran politik Islam berasal dari arus tradisi yang telah berkembang dalam masyarakat Indonesia sebagaimana tradisi Hindu-Jawa, sementara pemikiran politik sosialisme berasal dari arus modern khususnya yang berasal dari pemikiran barat. Kalaupun terdapat persinggungan pemikiran sebagaimana yang diadopsi oleh Partai Masyumi, maka persinggungan pemikiran tersebut terjadi oleh karena digunakan dan dikembangkannya kedua arus pemikiran yang berbeda tersebut oleh kader-kader partai yang bersangkutan.

Dalam tradisi pemikiran politik Barat, sosialisme berkembang karena terjadinya ketimpangan, kemiskinan dan eksploitasi yang menimpa individu pada abad ke 19, suatu fenomena yang justru terjadi bersamaan dengan munculnya dan 
berkembangnya industrialisasi dan demokrasi. Sosialisme oleh karenanya berkembang sebagai ideologi yang memfokuskan perhatiannya pada penderitaan kelompok individu dengan kekuasaan ekonomi, sosial dan politik yang relatif kecil (Danziger, 2005: 41).

Kaum sosialis meyakini bahwa manusia secara alamiah adalah mahluk sosial atau mahluk komunal. Individu tidak hidup atau bekerja secara terisolasi, melainkan dengan berkerja sama satu dengan yang lainnya. Kerjasama antar individulah, bukan kompetisi di antara mereka, yang dipahami oleh kaum sosialis sebagai fondasi dari masyarakat dimana setiap orang dapat menikmati secara layak kebebasan, keadilan dan kesejahteraan (Ball and Dagger, 2004:115).

Dalam pandangan kaum sosialis, kepemilikan pribadi merupakan sumber dari pembagian kelas yang akan menempatkan sebagian individu pada posisi pemegang kekuasaan dan memiliki privilese, sementara sebagian individu lainnya menjadi miskin dan tidak memiliki kekuasaan. Oleh karenanya sosialisme menawarkan program-program yang akan mendistribusikan kesejahteraan dan kekuasaan secara lebih merata di dalam masyarakat. Hal ini dikarenakan semua hasil produksi individu pada tingkatan tertentu adalah produk sosial, dan semua orang yang berpartisipasi dalam proses produksi mempunyai hak untuk menikmatinya. Dengan demikian masyarakat secara keseluruhanlah, bukan individu tertentu, yang harus memiliki dan mengontrol properti demi kebaikan atau manfaat seluruh anggota masyarakat (Ball and Dagger, 2004: 115).

Salah satu tokoh yang seringkali diasosiasikan dengan ideologi sosialisme adalah Karl Marx (Ball and Dagger, 2004: 115).Karl Marx bersama Friedrich Engels - merupakan pemikir politik yang menginisiasi varian sosialisme yaitu Marxisme. Marx mengkritik keberadaan kapitalisme, yang menurutnya mengakibatkan negara semata-mata hanya menjadi komite eksekutif untuk mengelola urusan-urusan kelas borjuis dan menciptakan sistem dimana kelas borjuis melakukan eksploitasi terhadap kelas pekerja (proletar) (Blaisdell, 2003: 126-135).

Marxisme membangun tiga asumsi terkait dengan perubahan yang diperlukan untuk melahirkan kesetaraan dan keadilan sosial. Pertama, orde sosioekonomi lama akan menolak perubahan dengan cara apapun, oleh karenanya perubahan memerlukan penggulingan orde lama dengan cara kekerasan. Kedua, transformasi menuju sosialisme merupakan perubahan yang kompleks dan sulit untuk dilakukan. Dengan demikian diperlukan pemerintahan yang kuat, yang antara lain bertugas untuk merestrukturisasi sistem ekonomi, dengan kepemilikan publik terhadap seluruh sumber daya penting dalam masyarakat, produksi serta distribusi barang dan jasa untuk kebutuhan individu. Ketiga, kelompok kecil kepemimpinan diktatorial diperlukan untuk mengelola pemerintahan dan melaukan perubahan yang kompleks dalam ekonomi dan masyarakat. Ketika kesetaraan relatif telah dicapai, kelompok kepemimpinan kecil dan pemerintahan yang kuat kemudian dapat dihilangkan (Danziger, 2005: 42-43).

Varian kedua dari Sosialisme adalah sosialisme demokratik. Varian ini juga meletakkan egalitarianisme sebagai tujuan utama, namun mengasumsikan bahwa perubahan dapat dilakukan oleh pemerintahan yang mendapatkan kekuasaan dengan cara-cara demokratis, tidak melalui kekerasan atau represi. Dalam sosialisme demokratik, kebijakan-kebijakan negara ditekankan pada pengurangan secara substansial ketidak setaraan dalam kondisi-kondisimaterial, kekuasaan dan status, namun tidak diarahkan untuk mencapai kesetaraan penuh dalam kondisi material. Ideologi ini antara lain dikembangkan oleh Thomas More, Robert Owen, dan ClaudeHenry St. Simon (Danziger, 2005: 43)

Di samping perbedaan pandangan antara varian sosialisme tersebut di atas, terdapat beberapa persamaan diantara varian tersebut yaitu (Hoffman and Graham, 2009: 220):

1. Pandangan optimistik terhadap sifat alamiah manusia (human nature), dimana hal tersebut dapat berubah dan tidak membentuk halangan terhadap regulasi sosial dan kepemilikan. Pandangan bahwa manusia sangat egois sehingga sulit untuk bekerja sama dan mempunyai kepentingan yang sama dengan demikian kontradiktif dengan doktrin sosialis.

2. Penekanan pada kerja sama. Semua orang dapat dan harus bekerja bersama sehingga pasar dan kapitalisme memerlukan beberapa penyesuaian untuk memfasilitasi kerja sama tersebut.

3. Pandangan positif tentang kebebasan. Kebebasan harus diletakkan dalam konteks sosial 
dan dalam konteks sumber daya material. Sebagai contoh, hak untuk membaca dan menulis, memerlukan pengaturan yang terkait dengan sekolah sehingga hak tersebut menjadi berarti.

4. Dukungan terhadap kesetaraan. Kesetaraan merupakan nilai mendasar dari masyarakat sosialis.

Namun demikian, pemikiran politik tentang sosialisme Islam yang dikemukakan oleh H.O.S. Tjokroaminoto nampaknya dibangun melalui asumsi yang berbeda. Tjokroaminoto tidak melihat sosialisme Islam sebagai penggabungan antara dua pemikiran yaitu ajaran sosialismeyang berasal dari Barat dan ajaran Islam. Sebagaimana dikemukakan oleh Tjokroaminoto dalam Islam dan Sosialisme, cita-cita sosialisme di dalam Islam telah berkembang selama tiga belas abad dan tidak dapat dikatakan muncul dari pengaruh bangsa Eropa (Tjokroaminoto: 2010: 22). Bahkan pada masa kepemimpinan Rasullullah Muhhamad S.A.W asas-asas sosialisme telah diimplementasikan lebih banyak dan lebih mudah dibandingkan dengan sosialisme yang dikenal dalam pemikiran Barat (Tjokroaminoto, 2010: 22). Sosialisme Islam yang dikemukakan oleh Tjokroaminoto dengan demikian diyakini olehnya tidak bersumber dan dipengaruhi oleh pemikiran politik yang berasal dari barat, melainkan merupakan pemikiran yang secara inheren terkandung di dalam ajaran Islam.

Pemikiran yang serupa dengan ajaran sosialisme yang dikembangkan oleh Islam antara lain juga dikemukakan oleh Hassan Hanafi dengan istilah Kiri Islam (The Islamic Left). Kiri Islam dapat difahami melalui pengertian yang diungkapkan oleh A.G Salih yang menyatakan bahwa "dalam Islam, Kiri memperjuangkan pemusnahan penindasan bagi orang-orang miskin dan tertindas, ia juga memperjuangkan persamaan hak dan kewajiban di antara seluruh masyarakat. Singkat kata, Kiri adalah kecenderungan sosialistik dalam Islam." (Shimogaki, 1993: 6).

Sebagaimana diungkapkan oleh Hassan Hanafi, Kiri Islam ditopang oleh tiga pilar untuk mewujudkan kebangkitan Islam. Pilar pertama adalah revitalisasi terhadap khazanah Islam klasik melalui rasionalisme demi kemajuan, kesejahteraan serta upaya memecahkan situasi kekinian dalam dunia Islam. Pilar kedua adalah penentangan terhadap peradaban Barat, terkait dengan bahaya imperialisme kultural Barat yang cenderung membasmi kebudayaan bangsabangsa yang secara kesejarahan kaya. Pilar ketiga adalah analisis terhadap realita dunia Islam (Shimogaki, 1993: 7-8).

Kiri Islam menurut Hassan Hanafi hadir sebagai kritik terhadap beberapa kondisi yaitu (Shimogaki, 1993: 91-92)-8):

1. Berbagai tendensi keagamaan yang terkooptasi kekuasaan menjadikan Islam hanya sekedar ritus dan kepercayaan-kepercayaan ukhrawi dimana gebyar ritus-ritus dan perayaan-perayaan itu justru menjadi topeng yang menyembunyikan wajah dominasi Barat dan kapitalisme nepotis. Sedangkan kecenderungan keagamaan lain yang tidak terkooptasi, terjebak ke dalam fanatisme primordial, kejumudan, dan berorientasi kekuasaan.

2. Liberalisme yang pernah berkuasa ternyata didikte oleh kebudayaan Barat, berperilaku seperti penguasa kolonial dan hanya melayani kelas-kelas elit yang menguasai aset negara, sementara mayoritas rakyat ditempatkan di luar lapangan permainan.

3. Marxisme yang berpretensi mewujudkan keadilan sosial dan menentang kolonialisme ternyata tidak diikuti dengan pembebasan rakyat dan pengembangan khazanah mereka sebagai energi untuk mewujudkan tujuantujuan kemerdekaan nasional.

4. Nasionalisme revolusioner yang berhasil melakukan perubahan-perubahan radikal dalam sistem politik dan ekonomi ternyata tidak berumur lama, banyak mengandung kontradiksi dan tidak mempengaruhi kesadaran mayoritas rakyat.

Mengacu pada pandangan di atas, gerakan Kiri Islam tidak menempatkan diri sebagai gerakan yang memiliki keterkaitan dengan pemikiran politik Barat, termasuk di dalamnya sosialisme dan marxisme. Bahkan gerakan Kiri Islam mengkritik marxisme yang dianggap gagal untuk memujudkan tujuan-tujuan kemerdekaan nasional pada negara-negara Islam.

Namun demikian, apabila dicermati lebih mendalam, terdapat beberapa kemiripan prinsip-prinsip yang dianut oleh Kiri Islam dan sosialisme. Hal ini antara lain dapat dilihat dari misi Kiri Islam yang terlihat dibangun di atas 
perspektif sosialis sebagai berikut (Shimogaki, 1993: 129)

1. Memanifestasikan keadilan sosial di kalangan umat Islam dan menciptakan masyarakat tanpa kelas, agar jurang yang menganga antar kaum miskin dengan orang kaya dapat terhapus, senafas dengan nash Al-Quran.

2. Menegakkan masyarakat yang bebas dan demokratis, di mana setiap individu berhak mengungkapkan pendapat, menyuarakan kritik dan melakukan amar ma'ruf nahi munkar.

3. Membebaskan tanah-tanah kaum muslimin dari kolonialisme di Palestina, menghapus pakta-pakta militer di dunia Islam dan mengembalikan kekayaan kaum muslimin setelah sekian lama sumber daya yang dimilikinya dihisap oleh imperialisme.

Misi Kiri Islam tersebut menunjukkan persamaan dengan prinsip-prinsip dalam sosialisme dan marxisme. Sebagaimana telah dibahas, salah satu prinsip sosialisme adalah mewujudkan keadilan sosial dan menunjukkan keberpihakan terhadap masyarakat yang miskin. Bahkan, masyarakat tanpa kelas (classless society) sejatinya merupakan tujuan dari marxisme (Blaisdell, 2003: 142).

Kesamaan dalam prinsip tersebut juga diakui oleh Kiri Islam yang menyatakan kesepakatannya terhadap tujuan-tujuan kebebasan, demokrasi dan keadilan yang diusung oleh sosialisme Barat. Kaum Marxis juga dianggap berjasa dalam peperangan melawan kolonialisme dan memperkuat kesadaran kelas buruh, pembentukan karakter revolusioner di kalangan mahasiswa dan keaktifannya dalam rintisan-rintisan persatuan mahasiswa dan buruh (Shimogaki, 1993: 135). Dengan demikian pemikiran Marxis pada dasarnya tidak bertentangan dengan Kiri Islam. Namun demikian, Kiri Islam mengklaim pemikirannya digali dari akar kebudayaan rakyat, sebagai tradisi yang menghidupi sanubari, imajinasi dan memberikan arah pada pergerakan rakyat secara turun temurun, sehingga tidak membutuhkan terminologi-terminologi filosofis yang lahir dari kebudayaan Barat (Shimogaki, 1993: 137).

Kiri Islam sebagaimana dinyatakan oleh Hassan Hanafi dengan demikian mengklaim dirinyasecarakeseluruhanterbebas daripeng-aruh Barat dan bahkan Timur. Kiri Islam bukanlah neo-marxisme, liberalisme revolusioner, Khawarij, Syi'ah ataupun gerakan Qaramitah, melainkan refleksi pemikiran historis yang merepresentasikan suatu gerakan sosial politik dalam khazanah klasik dengan menggali akarnya pada Al-Quran dan AsSunnah dan hanya bertujuan untuk kesejahteraan rakyat (Shimogaki, 1993: 140). Hassan Hanafi bahkan menekankan pandangannya sebagai berikut:

“"Kiri Islam bukanlah Islam yang dibungkus marxisme karena hal tersebut menafikan makna revolusioner dari Islam sendiri dan mengingkari tuntutan kaum muslimin terhadapkemerdekaan, persamaan, dan keadilan sosial. 'Kiri Islam' bukan pula marxisme yang berbaju Islam, karena hal itu berarti pengecut. Dan juga bukan pertautan eklektik di antara keduanya. Karena pertautan seperti itu mencerminkan pemikiran yang tidak mengakar dan tercerabut dari realitas rakyat. Tidak ada sedikitpun pengaruh marxisme dalam Kiri Islam, baik dalam bentuk maupun substansi. Ia murni merefleksikan realitas kaum muslimin, dengan menggali akar-akar revolusi kontemporer mereka dalam sejarah, peradaban dan sumber utama mereka: AlQuran dan Al-Sunnah.”

Berdasarkan hal tersebut di atas, walaupun tidak dapat dipungkiri terdapat kesamaan-kesamaan prinsip diantara sosialisme dari 'Kiri Islam' dan sosialisme yang berasal dari pemikiran Barat yaitu prinsip-prinsip yang terkait dengan kesetaraan, keadilan dan kesejahteraan. Namun kedua pandangan tentang sosialisme tersebut terbentuk dari dua latar belakang dan tradisi yang berbeda. Sosialisme yang dikembangkan oleh 'Kiri Islam' adalah sosialisme yang dibangun atas dasar Al-Quran dan As-Sunnah, sementara sosialisme Barat lahir sebagai reaksi terhadap perkembangan masyarakat Industri di Eropa abad ke-19.

H.O.S. Tjokroaminoto dalam pembahasan tentang sosialisme Islam secara spesifik menyebut bahwa sosialisme yang dimaksudnya adalah sosialisme yang bersandar kepada agama (Islam) yang wajib dilakukan oleh umatnya sepanjang hal tersebut merupakan perintah agama Islam. Sosialisme sebagaimana dimaksud adalah sosialisme yang telah berkembang kurang lebih selama tiga belas abad serta telah dipraktikkan sejak zaman Rasulullah Muhammad S.A.W. dan 
bukanlah sosialisme yang lahir dari pengaruh bangsa Eropa (Tjokroaminoto, 2010:22). Sosialisme Islam adalah pergerakan sosialisme yang dikontrol oleh identitas keislaman untuk mencapai kesempurnaan hidup di dunia maupun akherat (Nasihin, 2012: 150-151)).

Pandangan Tjokroaminoto dengan demikian menunjukkan bahwa sosialisme Islam bukanlah sosialisme yang lahir atau mendapatkan pengaruh dari sosialisme Barat, namun sosialisme yang didasarkan pada ajaran agama Islam. Praktik sosialisme Islam tersebut juga telah berkembang jauh sebelum sosialisme Barat berkembang di masyarakat Eropa pada abad ke-19, karena sosialisme Islam telah diterapkan sejak periode kepemimpinan Rasulullah S.A.W.

Terdapat dua macam sosialisme yang di kenal oleh Islam, yaitu (Tjokroaminoto, 2010: 22-23):

1. Staats-sosialisme, baik yang bekerja dengan kekuatan satu pusat (gecentraliseerd) maupun yang bekerja dengan kekuatan gemeentegemeente (gedecentraliseerd).

2. Industri-sosialisme. Jika satu negeri bersifat sosialis, maka pekerjaan kerajinan (pabrikan, industri) harus diatur seluas-luasnya secara sosialis (gesocialiseerd) juga. Maka di dalam negeri yang demikian itu, keberadaan tanah menjadi pokok segala hasil dan pokok semua pekerjaan industri besar. Kalau hendak dijalankan seluas-luasnya land-socialisme dan staat-socialisme. Maka bentuk sosialisme ini lah yang terutama sekali dijalankan oleh Islam. Sejak Nabi Muhammad SAW memegang kekuasaan negara, maka negara itu segera diaturnya secara sosialis, dan semua tanah dijadikannya sebagai milik negara.

Berdasarkan model sosialisme tersebut di atas, maka negara baik di tingkat pusat maupun daerah memegang peranan penting dalam praktik sosialisme. Salah satu tugas dari negara adalah penguasaan terhadap tanah sehingga tidak dikenal pemilikan pribadi.

Mengapa negara harus menguasai tanah sehingga seluruh tanah yang ada dijadikan milik negara? Tanah menjadi milik negara agar dapat dimanfaatkan seluas-luasnya untuk kepentingan rakyat. Oleh karena itu, alat-alat produksi yang dapat menghasilkan barang diberikan negara kepada rakyat (Tjokroaminoto, 2010: 23). Tanah dimanfaatkan untuk memberikan sebesar-besar- nya dan seluas-luasnya pekerjaan kepada kaum pekerja (Tjokroaminoto, 2010: 27).

Tjokroaminoto juga menggambarkan perbedaan sosialisme Islam dan sosialisme Barat dalam konteks pemerintahan (government). Sosialisme Barat yang menerapkan demokrasi sosialisme dimana pemerintahan mengadopsi sistem perwakilan menurutnya bukanlah sosialisme dalam arti kata yang sebenarnya karena sistem tersebut merupakan sistem demokrasi. Di dalam sistem sosialisme, seharusnya rakyat mempunyai suara langsung dalam masalahmasalahnegara.DalamsosialismeIslam, masalah tersebut terpecahkan oleh karena kekuasaan membentuk peraturan tidak diserahkan kepada kabinet atau parlemen atau golongan partai yang mewakili kepentingan kelompok atau kelas tertentu. Peraturan-peraturan muslim adalah peraturan yang berasal dari Tuhan yang berdiri di atas segala apa saja, sehingga tidak ada individu atau kelompok tertentu yang dapat mengubah peraturan-peraturan untuk kesenangan atau kepentingannya sendiri (Tjokroaminoto, 2010: 24).

Oleh karena peraturan berasal dari Tuhan dan hanya Tuhanlah yang dapat membentuk peraturan, maka dapat dipastikan tidak ada peraturan yang hanya mengakomodasi kepentingan individu atau kelompok tertentu. Peraturan yang berasal dari Tuhan adalah peraturan yang adil yang mengakomodasi kepentingan semua individu dan kelompok yang ada di dalam negara.

Pemerintah diperlukan tidak dalam fungsi membentuk peraturan, namun terkait dengan cara menjalankan peraturan. Pemerintah dengan demikian terdiri dari orang-orang yang mampu memberikan kebijaksanaan. Pemerintah yang mengadopsi sistem perwakilan ini diperlukan agar peraturan dapat dijalankan dengan baik. Kepala-kepala pemerintahan menjadi alat untuk menolong dari kesusahan dan mewujudkan harapan-harapan, serta untuk menjalankan peraturan Tuhan yang didasarkan pada kehendak seluruh rakyat (Tjokroaminoto, 2010: 25).

Sistem pemerintahan sosialisme Islam menurut Tjokroaminoto adalah sistem sebagaimana pernah diterapkan oleh Khalifah Umar bin Khatab. Sistem pemerintahan tersebut secara tegas menjunjung tinggi nilai-nilai kemanusiaan dan persamaan (dalam hal apapun) di antara sesama manusia tanpa kecuali (Nasihin, 2012: 163). 
Sosialisme Islam menentang kapitalisme, karena Islam melarang (mengharamkan) riba. Hal-hal yang terkait dengan tindakan eksploitasi, seperti memakan hasil pekerjaan orang lain, tidak memberikan bagian keuntungan yang seharusnya menjadi bagian dari orang yang bekerja dan berkontribusi terhadap keuntungan tersebut, dilarang oleh Islam karena termasuk ke dalam perbuatan memakan riba (Tjokroaminoto, 2010: 27). Oleh karenanya, Islam bertentangan dengan kapitalisme karena dasar dari kapitalisme adalah memakan riba yang diharamkan oleh hukum Islam.

Salah satu contoh praktik sosialisme Islam yang diterapkan oleh Nabi Muhammad menurut Tjokroaminoto adalah ketika Rasulullah S.A.W. mengangkat derajat budak belian menjadi orang merdeka. Budak-budak belian diberikan hak yang dulu tidak dimiliki dengan menjadikan mereka sebagai teman kerja, kepala prajurit atau pemimpin berbagai jenis pekerjaan, dan dalam beberapa hal mengangkat para budak belian menjadianggotadalamkeluarga(Tjokroaminoto, 2010: 27-28). Praktik sosialisme Islam tersebut bahkan sulit ditemukan di dalam masyarakat industri modern Barat, dimana kaum pekerja seringkali menjadi obyek eksploitasi dari para pengusaha dan kaum pemilik modal.

Tjokroaminoto juga membahas perbedaan sosialisme Islam dengan ajaran marxisme. Menurutnya, umat Islam tidak boleh dan tidak dapat menerima pandangan Karl Marx karena beberapa alasan. Marx tidak mengakui keberadaan agama bahkan menyatakan bahwa agama itu adalah kebingungan otak, yang dibuat-buat oleh manusia untuk meringankan beban hidup yang sukar, sehingga agama merupakan candu bagi rakyat. Selain itu ajaran materialisme historis menyatakan bahwa segala sesuatu berasal dari benda, oleh benda, dan kembali ke benda. Padahal, umat Islam meyakini bahwa segal sesuatu berasal dari Allah, oleh Allah dan akan kembali kepada Allah. Ajaran materialisme historis dengan demikian tidak hanya memungkiri keberadaan Allah, namun juga mempertuhankan benda (Tjokroaminoto, 2010: 31-36).

Pandangan Tjokroaminoto tersebut di atas memperlihatkan ketiadaan keterkaitan antara sosialisme Islam dengan sosialisme Barat khususnya Marxisme, karena perbedaan cara pandang yang fundamental tentang keberadaan agama dan Tuhan. Marxisme menyatakan bahwa agama diciptakan sebagai alat pengalih perhatian dari kesulitan yang dihadapi oleh masyarakat, dan tidak mengakui keberadaan Tuhan. Sebaliknya, sosialisme Islam meyakini keberadaan Allah yang menurunkan agama sebagai alat atau cara untuk menyelesaikan persoalan-persoalan yang ada dalam masyarakat.

Terkait dengan hal-hal yang menjadi dasar dari sosialisme Islam, Tjokroaminoto mengemukakanhal-hal sebagaiberikut(Tjokroaminoto, 2010: 37-38):

1. Dasar sosialisme Islam adalah ajaran dalam Al-Quran (Surat Al-Baqarah ayat 213) yang menyatakan bahwa seluruh umat manusia itu bersaudara atau bersatu (kaanan nasu ummatan wahidatan). Oleh karena umat manusia bersaudara dan bersatu, maka merupakan kewajiban seluruh individu untuk mencapai keselamatan bersama.

2. Al-Quran juga mengajarkan umatnya untuk menciptakan perdamaian, selain itu terdapat ajaran bahwa Allah telah memisah-misahkan kita menjadi golongan-golongan dan sukusuku agar supaya kita mengenal satu sama lain (QS Al-Hujurat:12).

3. Rasulullah S.A.W. bersabda bahwa Allah telah menghilangkan kecongkakan dan kesombongan di atas asal turunan yang tinggi, sehingga seorang Arab tidak lebih tinggi dan mulia daripada seorang asing, melainkan karena takut dan baktinya kepada Allah.

4. Rasulullah S.A.W. juga bersabda bahwa Allah hanyalah satu, dan asalnya sekalian manusia itu hanyalah satu, dan mereka mempunyai agama hanyalah satu juga.

Ajaran-ajaran yang bersumber dari AlQuran dan As-Sunnah sebagaimana tersebut di atas dengan demikian menurut Tjokroaminoto menunjukkan bahwa anak Adam merupakan satu anggota badan yang beraturan (organisch lichaam) karena mereka dijadikan dari satu hal. Apabila salah satu anggotanya sakit, maka penyakit tersebut akan menjadikan kerusakan bag segenap badan. Hal inilah yang bagi Tjokroaminoto menjadi pokok dari sosialisme sejati, yaitu sosialisme cara Islam bukanlah sosialisme cara Barat (Tjokroaminoto, 2010: 38).

Ajaran sosialisme Islam menurut Tjokroaminoto tidak hanya berupa teori-teori 
namun berupa praktik yang dijalankan dalam kehidupan sehari-hari oleh umat Islam, bahkan beberapa diantara merupakan praktik yang wajib dilaksanakan oleh kaum muslim. Dengan demikian, ajaran sosialisme Islam tidak hanya bersifat tekstual dan normatif belaka namun diterjemahkan dalam kehidupan sehari-hari sebagai sebuah perilaku sehari-hari umatnya (Nasihin, 2012: 155). Beberapa contoh praktik sosialisme Islam tersebut antara lain:

1. Semua umat Islam, kaya atau miskin, dari berbagai macam suku bangsa dan warna kulit, pada setiap Jum'at diwajibkan untuk berkumpul dan menjalankan shalat di mesjid dengan tidak mengadakan perbedaan sedikitpun tentang tempat atau derajat, di bawah pimpinan orang yang dipilih dalam perkumpulan itu.

2. Dua kali dalam setahun penduduk suatu kota atau tempat berkumpul untuk melaksanakan shalat - Idul Fitri dan Idul Adha - dan berjabat tangan serta berangkulan satu sama lain dengan rasa persaudaraan.

3. Setiap umat Islam diwajibkan - bagi yang mampu - untuk mengunjungi Mekah dalam rangka menunaikan ibadah haji pada waktu yang telah ditentukan untuk berkumpul di suatu tempat dengan pakaian yang sama dan sangat sederhana, terlepas dari tinggi dan rendah derajatnya dan perbedaaan bangsa dan warna kulit.

Contoh-contoh tersebut di atas menurut Tjokroaminoto merupakan bentuk sosialisme cara Islam dalam rangka mewujudkan persamaan dan persaudaraan. Praktik tersebut akan menanamkan perasaaan bahwa semua manusia itu satu persatuan dan diwajibkan kepada mereka untuk berlaku satu sama lain dengan persamaan yang sempurna sebagai anggota satu persaudaraan (Tjokroaminoto, 2010: 40).

Ajaran Islam lainnya yang bersifat sosialistik adalah perilaku kedermawanan. Dalam AlQur-an, pemberian sedekah tidak hanya terkait dengan kebajikan namun merupakan kewajiban yang tidak boleh dilalaikan. Salah satu firman Allah mengkaitkan perilaku kedermawanan dengan keadilan: "Kamu tidak pernah akan dapat mencapai keadilan kecuali apabila kamu telah memberikan daripadanya apa yang kamu cintai, dan Tuhan mengetahui apa yang kamu berikan itu".
Perintah tentang kedermawanan menurut Tjokroaminoto mempunyai tiga dasar sosialistik (Tjokroaminoto, 2010: 43):

1. Akan membangunkan rasa ridla mengorbankan diri dan rasa melebihkan keperluan umum daripada keperluan diri sendiri.

2. Akan membagi kekayaan sama rata di dalam dunia Islam.

3. Untuk menuntun perasaan orang, supaya tidak menganggap kemiskinan itu satu kehinaan.

Tjokroaminoto juga mengungkapkan tiga komponen yang terdapat di dalam sosialisme dan ketiganya dimuat dalam berbagai peraturanperaturan Islam dan diimplementasikan oleh Rasullullah Muhammad S.A.W., yaitu kemerdekaan(vrijheid-liberty), persamaan (gelijkhiedequality) dan persaudaraan (broederschapfraternity) (Tjokroaminoto, 2010: 46). Berbagai ayat dalam Al-Quran maupun hadits Rasullulah mengatur tentang hal-hal yang terkait kemerdekaan, persamaan dan persaudaraan.

Tidak hanya Rasulullah S.A.W., sahabatsahabat nabi pun mempraktikkan sosialisme Islam dalam kehidupannya. Sayidina Ali R.A., seringkali mendoakan musuhnya sendiri dan memberikan segala harta benda miliknya untuk keperluan orang banyak. Sayidina Umar R.A., seringkali tidur bersama-sama orang miskin dan ketika dalam perjalanan menaklukkan Palestina. Bersama budaknya menunggang unta secara bergiliran. Sayidina Abubakar R.A., ketika diangkat menjadi pemimpin menyatakan bahwa dirinya bukanlah orang yang paling utama diantara umat dan justru merasa sangat perlu mendapatkan nasehat dan contoh perbuatan dari umat Islam lainnya. Sayidina Usman R.A. dengan biayanya sendiri membeli banyak sumber air dan dijadikan kepunyaan orang banyak untuk keselamatan rakyatnya. Ia juga banyak memerdekakan budak-budaknya.

Sosialisme Islam, sebagaimana diungkapkan oleh Tjokroaminoto, dengan demikan merupakan perwujudan kehidupan yang adil, setara, merata untuk mencapai kesejahteraan yang didasarkan oleh nilai-nilai tauhid. Sosialisme Islam merupakan suatu sistem sosial, budaya, ekonomi dan politik yang tidak hanya berupa konsep namun dipraktikkan oleh umatnya, dan bahkan pada tingkatan tertentu berupa kewajiban untuk menjalankan praktik-praktik tersebut. 


\section{PENUTUP}

Pemikiran politik H.O.S. Tjokroaminoto tentang sosialisme Islam memberikan gambaran tentang faham sosialisme yang dibangun atas dasar ajaran agama Islam, yang inti ajaran bersumber dari Al-Quran dan As-Sunnah. Sosialisme Islam yang dikemukakan oleh Tjokroaminoto merupakan sosialisme yang telah berjalan sejak masa kepemimpinan Rasulullah S.A.W dan para sahabatnya. Dengan demikian sosialisme Islam tidaklah dipengaruhi oleh faham sosialisme yang berasal dari Barat yang baru berkembang pada abad ke-19. Pemikiran politik sosialisme Islam tersebut dengan demikian mempunyai kesamaan dengan pemikiran Kiri Islam, yang menempatkan Al-Quran dan As-Sunnah sebagai sumber utama pergerakannya.

Namun demikian, terdapat prinsip-prinsip sosialisme yang serupa antara sosialisme Islam dengan sosialisme Barat. Prinsip keadilan, kesetaraan, dan persaudaraan merupakan prinsip yang dipegang teguh baik oleh sosialisme Islam maupun sosialisme Barat. Selain itu, sosialisme Islam dan sosialisme Barat sama-sama bertujuan menciptakan kesejahteraan bagi seluruh anggota masyarakat.

Selain persamaan, terdapat pula perbedaan antara sosialisme Islam dan sosialisme Barat. Sosialisme Islam dibangun atas dasar ketentuan atau aturan-aturan berdasarkan firman Allah S.W.Tatau hadist Rasulullah S.A,W. Sosialisme Islam juga dibangun atas dasar keyakinan terhadap keberadaan Allah S.W.T. sebagai dzat yang Maha Kuasa. Sosialisme Barat lahir dari kondisi masyarakat industri Eropa pada abad ke-19 dimana terjadi ketimpangan kondisi sosial, ekonomi dan politik. Sosialisme Barat dengan demikian tidak terkait dengan agama, sedangkan sosialisme Islam sangat terkait dengan ajaran agama.

\section{DAFTAR PUSTAKA}

Adams, Cindy. Bung Karno, Penyambung Lidah Rakyat Indonesia. Jakarta: Gunung Agung, 1966.
Ball, Terence and Richard Dagger. Political Ideologies and the Democratic Ideal. New York: Pearson, 2004.

Blaisdell, Bob (ed.). The Communist Manifesto and Other Revolutionary Writings: Marx, Marat, Paine, Mao, Gandhi, and Others. New York: Dover Publication Inc. 2003.

Danziger, James N. Understanding the Political World: A Comparative Introduction to Political Science. New York: Pearson, 2005.

Feith, Herbert Feith and Lance Castles. Indonesian Political Thinking 19451965. Jakarta: Equinox, 2007.

Gonggong, Anhar. H.O.S. Tjokroaminoto. Jakarta: Departemen Pendidikan dan Kebudayaan, 1985.

Hoffman, John and Paul Graham. Introduction to Political Theory. New York: Pearson, 2009.

Nasihin, Sarekat Islam Mencari Ideologi 19241945. Yogyakarta: Pustaka Pelajar, 2012.

Niel, Robert van. Munculnya Elit Modern Indonesia. Jakarta: Pustaka Jaya, 2009.

Rambe, Safrizal. Sarekat Islam Pelopor Bangkitnya Nasionalisme Indonesia 1905-1942. Jakarta: Kebangkitan Insan Cendekia, 2008.

Shimogaki,Kazuo. Kiri Islam antara Modernisme dan Postmodernisme, Telaah Kritis Pemikiran Hassan Hanafi. Yogyakarta: LKis, 1993.

Subekti, Valina Singka. Partai Syarikat Islam Indonesia, Kontestasi Politik hingga Konflik Kekuasaan Elite. Jakarta: Pustaka Obor Indonesia, 2014.

Tjokroaminoto, H.O.S. Islam dan Sosialisme. Bandung: Sega Arsy, 2010. 